УДК 616.748-005.4-036.11-089.811]-092.9

DOI 10.11603/bmbr.2706-6290.2020.2.11384

М. В. Ющак, А. Т. Телев’як, П. Р. Сельський, О. М. Герман, Б. П. Сельський, В. А. Проців

Тернопільський начіональний медичний університет імені I. Я. Горбачевського МОЗ Украӥни

\title{
СТРУКТУРНІ ЗМІНИ В АРТЕРІЯХ ЗАДНІХ КІНЦІВОК ЩУРІВ ПРИ ГОСТРІЙ ІШЕМІЇ-РЕПЕРФУЗІї
}

\section{Структурні зміни в артеріях задніх кінцівок щурів} при гострій ішемії-реперфузії

М. В. Ющак, А. Т. Телев'як, П. Р. Сельський, О. М. Герман, Б. П. Сельський, В. А. Проців

Тернопільський національний медичний університет імені І. Я. Горбачевського МОЗ України

Резюме. Артеріальні турнікети широко застосовуються як у клінічній практиці (зокрема при ангіо- та артропластиках), так і у військовій медицині при пораненнях кінцівки. Після зняття турнікета і відновлення кровопостачання кінцівки виникає мультифракторне ішемічно-реперсрузійне ураження як первинно ішемізованих, так і віддалених від місця ішемії тканин. Проте морфологіччні зміни в стінці магістральних артерій при гострій ішемії-реперфрузії у медичній літературі висвітлено недостатньо.

Мета дослідження - встановити особливості структурних змін стінок магістральних артерій задніх кінцівок щурів при гострій ішемії, спричиненій накладанням артеріального джгута.

Матеріали і методи. Проведено мікроскопічне дослідження гістологічних препаратів поперечних зрізів стегнової, підколінної та гомілкової артерії 30 щурів нижче від ділянки накладання джгута за умов експериментальної гострої ішемії. Гостру ішемію викликали шляхом накладання гумових джгутів SWAT на задні кінцівки тварин шириною 5-6 мм, на рівні пахвинної складки протягом 2 год під тіопенталовим знеболюванням, а реперфузію моделювали шляхом зняття турнікета. Під час експерименту тварин поділили на 5 груп дослідження по 6 щурів у кожній. Модель раннього постішемічного періоду була представлена групами тварин із реперфузійними змінами через 1 і 2 год та 1 добу після зняття турнікета, а модель пізнього реперфузійного періоду - групами тварин через 7 та 14 діб. Гістологічне дослідження проводили за загальноприйнятими методиками. Зрізи артерій забарвлювали гематоксиліном та еозином, резорцин-фруксином за Вейгартом, за ван Гізон та азаном за методом Гейденгайна, та вивчали за допомогою світлового мікроскопа.

Результати. Результати досліджень показали, що у ранньому реперфузійному періоді морфологічними критеріями ремоделювання артерій стегнової, підколінної та гомілкової ділянок є гістологічні зміни усіх структурних елементів їхньої стінки, які проявляються набряком і потовщенням усіх їі оболонок, значним набряком та відшаруванням ендотеліоцитів із розвитком пристінкового мікротромбозу, нерівномірною гофрованістю та (с). В. Ющак та ін., 2020
Structural changes in the arteries of the hind limbs of rats by acute ischemia-reperfusion

M. V. Yushchak, A. T. Televiak, P. R. Selskyy,

O. M. Herman, B. P. Selskyy, V. A. Protsiv

I. Horbachevsky Ternopil National Medical University

e-mail: yuschak@tdmu.edu.ua

Summary. Arterial tourniquets are widely used both in clinical practice (for example for angio- and arthroplasty) and in military medicine by the injury of the limbs. After removing the tourniquet and blood supply restoration to the limb arises a multifactorial lesion of tissues both ischemic and distant from the site of ischemia. However, morphological changes in the wall of the main arteries by the acute ischemia-reperfusion are insufficiently covered in the medical literature.

The aim of the study - to establish the peculiarities of structural changes of the main arteries of the rat's hind limbs by acute ischemia, caused by application of the arterial tourniquet.

Materials and Methods. The microscopic study of histological preparations with transverse sections of the femoral, popliteal and tibial arteries of the hind limbs of 30 rats under condition of experimental acute ischemia was performed. Acute ischemia was caused by application of SWAT rubber bands on the hind limbs of animals, 5-6 $\mathrm{mm}$ in width, at the inguinal fold level within 2 hours under thiopental anesthesia. A reperfusion was modeled by removing the tourniquet. During the experiment, all the animals were divided into 5 study groups of 6 rats in each group. The model of the early postischemic period was represented by groups of animals with reperfusion changes on the 1st, 2nd hour and 1st day after removal of the tourniquet, and model of the late reperfusion period was represented by groups of animals with reperfusion changes on the 7th and 14th day after tourniquet removal. The histological examination was carried out according to standard methods. Sections of the arteries were stained with hematoxylin and eosin, with resorcinol-fuchsin according to Weigart, according to method of Van Gizon and azan according to the method of Heidenhain, and were examined with a light microscope.

Results. Morphometric studies had established that morphological criteria of remodeling of the arteries of the femoral, popliteal and tibial areas during the early reperfusion period were histological changes of all structural elements of their wall, which were manifested by edema and thickening of all its layers, significant edema and exfoliation of endothelial cells with the development of parietal microthrombosis, uneven corrugation and ruptures 
розривами базальної мембрани, порушенням цілості еластичних волокон, вакуолізацією саркоплазми лейоміоцитів, лейкоцитарною інфільтрацією м'язової оболонки та перивазального простору, а також периваскулярними діапедезними крововиливами. у пізньому репероузійному періоді вираження вищезазначених змін різко зменшується, водночас відбувається розвиток грануляційної тканини у периваскулярному просторі магістральних артерій задніх кінцівок щурів.

Висновки. Результати морфологічного дослідження підтверджують ремоделювання стінок магістральних артерій задніх кінцівок щурів у результаті розвитку ішемічно-реперфузійного синдрому, яке проявлялося комплексом патоморфологічних змін усіх оболонок артерій, що досягали максимуму через 1 добу після зняття турнікета, і поступово зменшувалися у пізньому репероузійному періоді через 7 mа 14 діб.

Ключові слова: гостра ішемія; реперфузія; артерія; гістологічні зміни; ремоделювання; артеріальний турнікет.

\section{ВСТУП}

Артеріальні турнікети широко застосовуються як у клінічній практиці (зокрема при ангіо- та артропластиках), так і у військовій медицині при пораненнях кінцівки $[1,2]$. Після зняття турнікета і відновлення кровопостачання кінцівки виникає багатофракторне ішемічно-реперфузійне ураження як первинно ішемізованих, так і віддалених від місця ішемії тканин [3, 4].

Вивченню структурних змін гемомікроциркуляторного русла та м'яких тканин кінцівок при розвитку даного синдрому присвячено низку досліджень $[5,6]$, проте структурні зміни в магістральних артеріях кінцівок великого діаметра при розвитку ішеміїреперфузії залишаються вивченими недостатньо.

Метою дослідження було встановити особливості структурного ремоделювання стінок магістральних артерій задніх кінцівок щурів при гострій компресійній ішемії кінцівки та її наступній реперфрузії, спричиненій накладанням артеріального турнікета.

\section{МАТЕРІАЛИ I МЕТОДИ}

Проведено гістологічне дослідження артерій задніх кінцівок 30 щурів за умов експериментальної гострої ішемії-реперфузії. У контрольній групі було 5 інтактних тварин.

Досліди виконували в спеціально відведеному приміщенні Центральної науково-дослідної лабораторії Тернопільського національного медичного університету імені І. Я. Горбачевського МОЗ України, що полягали у моделюванні ішемії шляхом накладання гумового джгута SWAT на задню праву кінцівку тварини, на рівні пахвинної складки під тіопентал-натрієвим знеболюванням (40 мг х кг¹ маси тіла). Ширина перетискання тканин станови- of basal membrane, violation of integrity of elastic fibers, fragmentation of leiomyocytes with vacuolation of their sarcoplasm, leukocyte infiltration of the muscular layer and perivasal space, as well as perivascular diapedeous haemorrhages. During the late reperfusion period, the severity of the above-mentioned changes was significantly decreased, while simultaneously the development of granulation tissue in the perivascular space of the main arteries of the hind limbs of rats was happening.

Conclusions. The results of morphological study confirm the remodeling of the wall of main arteries of hind limbs of the rats as a result of the development of ischemia-reperfusion syndrome in experimental animals, which was manifested by a complex of pathomorphological changes of all arterial membranes. These changes reached a maximum on 1st day after removal of the tourniquet, and gradually decreased in the late reperfusion period after 7 and 14 days.

Key words: acute ischemia; reperfusion; artery; histological changes; remodeling; arterial tourniquet.

ла 5-6 мм. Реперфрузію моделювали шляхом відновлення кровообігу в раніше ішемізованій кінцівці унаслідок зняття кровоспинного турнікета через 2 год після його накладання.

Евтаназію тварин здійснювали шляхом декапітації під тіопентал-натрієвим знеболюванням (500 мг х кг ${ }^{1}$ маси тіла внутрішньочеревно), після чого проводили забір біологічного матеріалу. Дослідження проведені 3 дотриманням основних положень Закону України № 3447 - IV від 21.02.06 р. «Про захист тварин від жорстокого поводження» (2006), «Правил проведення робіт з використанням експериментальних тварин», затверджених Наказом МО3 України № 755 від 12.08.1997 р., Європейської конвенції про захист хребетних тварин, що використовуються для дослідних та інших наукових цілей (Страсбург, 1986), Директиви Ради Європи 2010/63 EU щодо експериментів на тваринах.

Під час експерименту тварин поділили на 5 груп дослідження. Модель раннього постішемічного періоду була представлена трьома групами тварин із репероузійними змінами через 1 і 2 год та 1 добу, а модель пізнього реперфузійного періоду двома групами тварин через 7 та 14 діб після зняття турнікета (по 6 щурів у кожній групі).

Гістологічне дослідження проводили на кафедрі патологічної анатомії із секційним курсом та судової медицини Тернопільського національного медичного університету імені І. Я. Горбачевського МОЗ України. Досліджували поперечні зрізи стегнової, підколінної та великогомілкових артерій нижче ділянки накладання джгута. 3 парафрінових блоків готували серії зрізів товщиною 4-5 мкм, виготовлені на мікротомі МС-2. Тканини фріксували в $10 \%$ розчині нейтрального фрормаліну, зневоднювали у спиртах наростаючої концентрації та просочували парафріном за загальноприйнятими методиками [7]. Гістологічні 
зрізи забарвлювали гематоксиліном та еозином, резорцин-фруксином за Вейгартом, за ван Гізон та азаном за методом Гейденгайна.

Гістологічні препарати вивчали за допомогою лабораторного мікроскопа MICROmedSEO SCAN та фотографували за допомогою фотоустановки Digital Camera for Microscope Science Lab DCM 820.

\section{РЕЗУЛЬТАТИ Й ОБГОВОРЕННЯ}

За допомогою гістологічного дослідження виявлено структурні зміни стінок магістральних артерій задніх кінцівок щурів у стегновій, підколінній та гомілковій ділянках нижче від місця накладання артеріального турнікета.

У контрольній групі щурів спостерігалася нормальна будова судинної стінки магістральних артерій (рис. 1). Інтима артерій рівномірно вкрита ендотелієм. У субендотеліальному просторі, гладких м'язових клітинах та адвентиції не спостерігалося дистрофрічно-дегенеративних та запальних змін. У стінці судин не виявлялося й ознак фріброзу та склерозу.

Проте вже через 1 год реперфузії структурні зміни мали місце в усіх шарах артеріальної стінки, які були набряклими та потовщеними. Найвираженіші зміни виявлялися в інтимі, яка була помірно потовщена порівняно з контрольною групою. Мали місце звивистість та порушення цілості внутрішньої еластичної мембрани в окремих ділянках. Унаслідок набряку цитоплазми більшість ендотеліоцитів набували округлої фрорми, їхні ядра були поліморфними: довгасті, витягнені, овальні та округлі. Виявлено також набряклі ядра з гіпохромією. Мало місце злущування окремих груп ендотеліоцитів. Субендотеліальні ділянки були незначно потовщені. Лише в окремих випадках виявлялися ділянки артерії із відшарованою базальною мембраною (рис. 2). Відбувалося також потовщення м'язових волокон з вакуолізацією саркоплазми в деяких з них. У м'язовій оболонці артерій візуалізувалися окремі лімфроцити.

Через 2 год після зняття джгута в артеріях стегнової, підколінної та гомілкової ділянок виявлялися подібні, проте більш виражені зміни порівняно із попереднім періодом. Необхідно зазначити, що при однотипності проявів порушення були більш вираженими в інтимі артерій стегнової ділянки, зокрема більш виразними виявлялися зміни їі гістоархітектоніки. Мало місце вираженіше потовщення субендотеліального шару. Гофрованість еластичних мембран була більш вираженою та нерівномірною (рис. 3). Адвентиція була набряклою та потовщеною. Периваскулярна тканина мала сітчастий вигляд. Серед сполучнотканинних волокон виявлялися лімфоцити.

На кінець 1-ї доби реперорузії, порівняно із попередніми термінами дослідження, прояви ремоделювання виявлялися найсуттєвішими. Мікроско-

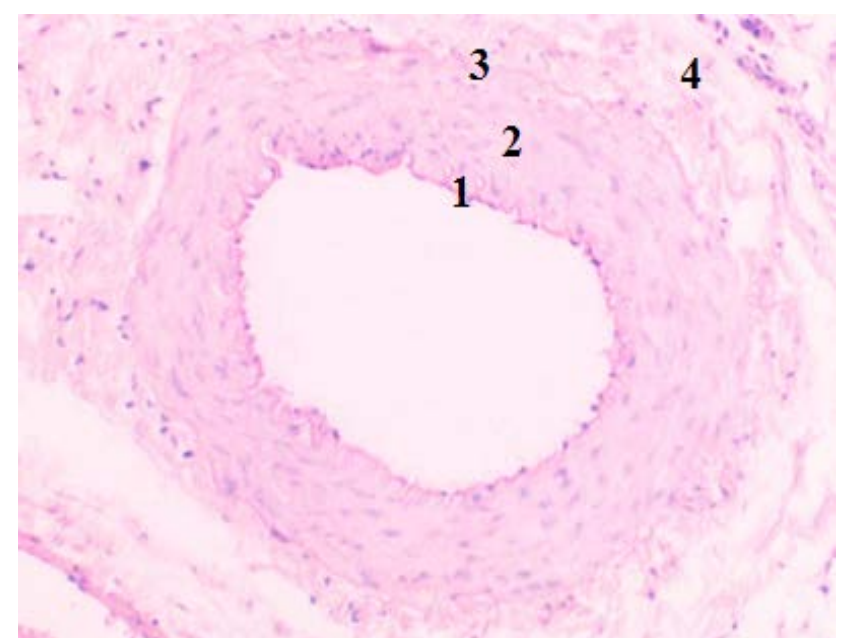

Рис. 1. Артерія стегнової ділянки щура. Контрольна група. Забарвлення гематоксиліном та еозином. ×100.

Примітка. 1 - інтима артерії; 2 - м'язова оболонка; 3 - адвентиція; 4 - периваскулярний простір.

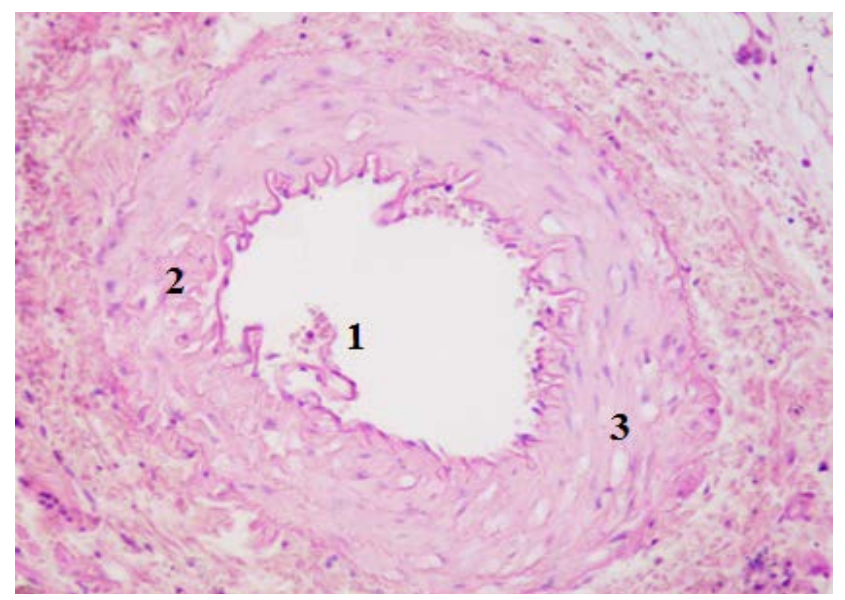

Рис. 2. Артерія стегнової ділянки. Реперфузія через 1 год. Забарвлення гематоксиліном та еозином. $\times 100$.

Примітка. 1 - відшарована інтима; 2 - субендотеліальний набряк м'язової оболонки; 3 - вакуолізація медії.

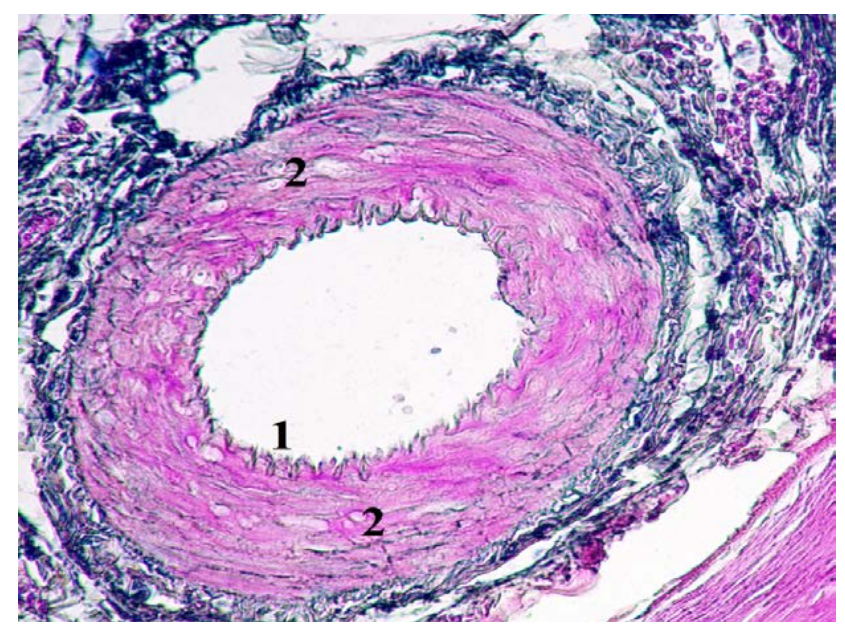

Рис. 3. Підколінна артерія. Реперфузія через 2 год. Забарвлення азаном за методом Гейденгайна. ×200.

Примітка. 1 - набрякла та гофрована еластична мембрана; 2 - набряклі та розволокнені м'язові волокна медії. 
пічне дослідження показало наростання уражень артеріального русла та їх комплексність.

У дослідних тварин зазначеної групи в усіх ділянках кінцівки виявлено подальше потовщення усіх оболонок артерій, що зумовлено набряком їхніх структур. Найвиразніше набрякала інтима. Ендотеліоцити набухали, набували округлих обрисів, спостерігалося їх пролабування у просвіт артерії (рис. 4). Цитоплазма була світлою, ядра - гіперхромні. У просвіті судин знаходили групи злущених ендотеліоцитів. Окрім цього в місцях ушкодженого ендотелію спостерігалися пристінкові агрегати еритроцитів.

Базальна мембрана артерій у цей період була нерівномірно гофрованою, нерідко із розривами в окремих місцях (рис. 5). Відповідно змінювалася архітектоніка інтими 3 ламінарної на гофровану. Виразні зміни спостерігалися в структурі еластичних волокон, відмічалися порушення їх цілості та фррагментація. Лейоміоцити середньої оболонки були нерівномірної товщини та звивистості, фррагментувалися, спостерігалося їх розволокнення та ділянки вакуолізації. Адвентиція артерій потовщувалася унаслідок розрихлення набряковою рідиною. В периваскулярних просторах також спостерігалися явища набряку.

У зазначеній групі дослідних тварин характерною була виражена інфільтрація медії (переважно лімфоцитарна), яка поширювалася і на зовнішню оболонку та периваскулярну тканину. В окремих випадках у периваскулярних ділянках та між м'язовими волокнами мали місце ділянки крововиливів. Периваскулярно подекуди виявлявся і некроз скелетних м'язів з інорільтрацією навколо некротичних зон. У паравазальній тканині спостерігався виражений набряк із розрихленням тканинних структур.

У пізньому реперфузійному періоді через 7 діб після зняття артеріального турнікета гістологічне дослідження магістральних артерій задніх кінцівок щурів показало структурні порушення, аналогічні виявленим у ранньому періоді реперфузії, а також низку нових гістологічних змін, характерних лише для пізнього періоду реперсузії. Структурні зміни мали місце в усіх оболонках судин, які були набряклими та потовщеними. Проте незважаючи на схожість цих проявів, їхня інтенсивність була значно менш вираженою порівняно з раннім реперфузійним періодом.

Еластичні мембрани зазвичай зберігали свою цілість, але гофрованість була нерівномірною, часто спостерігалося розволокнення еластичних волокон або навіть їхня фррагментація (рис. 6).

Унаслідок набряку цитоплазми більшість ендотеліоцитів мала округлу форму з овальними та округлими ядрами, були нормохромними, лише в окремих випадках виявлялася помірна гіперхро-

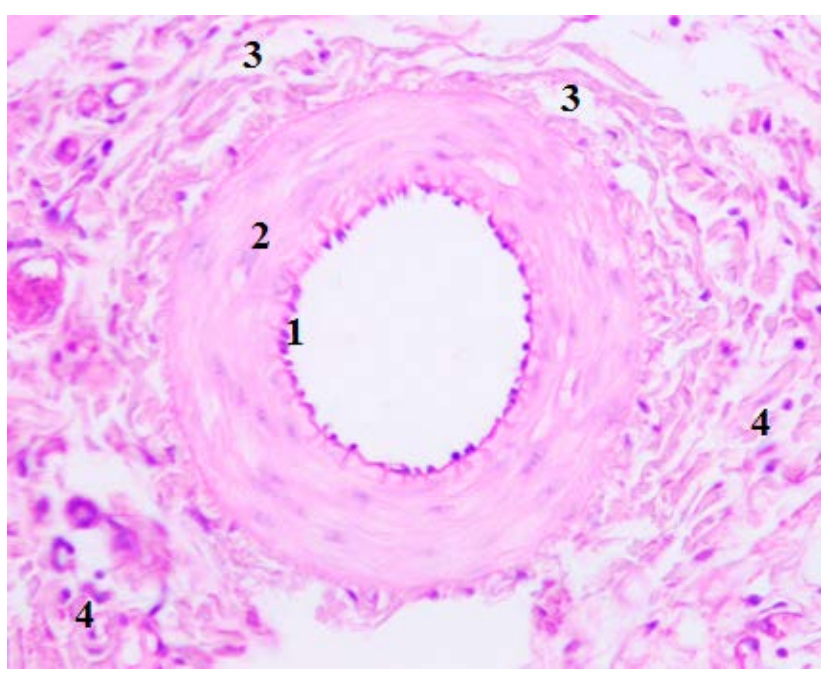

Рис. 4. Артерія гомілкової ділянки. Реперфузія через 1 добу. Забарвлення гематоксиліном та еозином. $\times 100$.

Примітка. 1 - пролабування ендотеліоцитів; 2 - набрякла стінка артерії; 3 - набряклий периваскулярних простір; 4 - клітинна інсрільтрація.

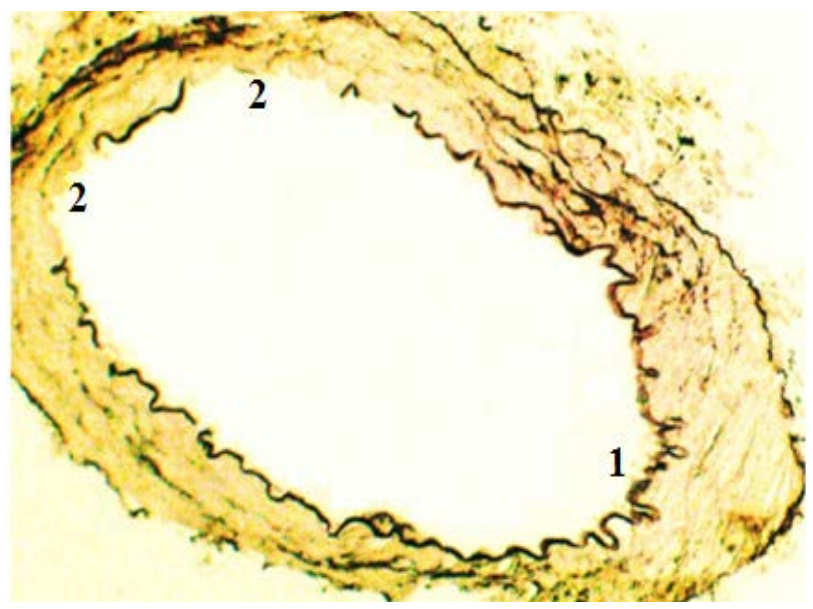

Рис. 5. Стегнова артерія. Реперфузія через 1 добу. Забарвлення за Вейгартом. $\times 200$.

Примітка. 1 - гофрована еластична мембрана; 2 - ділянки 3 розривами еластичної мембрани

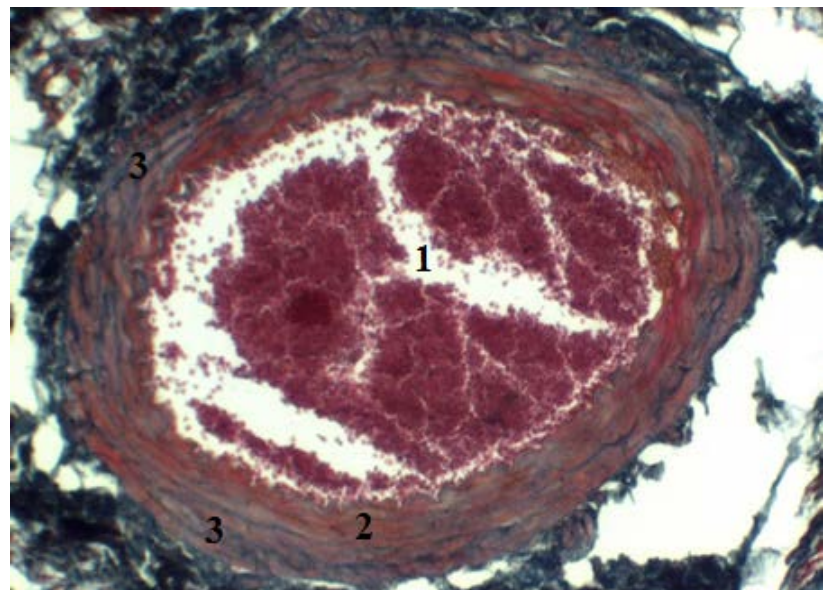

Рис. 6. Стегнова артерія. Реперфузія через 7 діб. Забарвлення азаном за методом Гейденгайна. ×100.

Примітка. 1 - просвіт артерії; 2 - набряклі та розволокнені м'язові волокна стінки артерії; 3 - розволокнені еластичні волокна. 
мія. Мало місце пролабування ендотеліоцитів у просвіт артерій задніх кінцівок щурів. При цьому виявлено злущування окремих ендотеліоцитів у просвіт судин.

Субендотеліальні ділянки були незначно набряклі. В окремих місцях виявлялося також розволокнення та вакуолізація м'язових пучків медії. У периваскулярному просторі та адвентицї спостерігався розвиток молодої грануляційної тканини зі значною кількістю судин та помірним накопиченням колагенових волокон (рис. 7), при цьому набряк був менш вираженим порівняно 3 попередньою групою. У даній ділянці, а також в адвентиції виявлялася лейкоцитарна інфільтрація, переважно лімфроцитарна.

На кінець 14-ї доби реперфузії, порівняно з попередніми термінами дослідження, прояви ремоделювання виявлялися найменше. Мікроскопічне дослідження показало повернення низки структурних змін артеріального русла до початкового стану.

Водночас у дослідних тварин зазначеної групи в артеріях усіх ділянок спостерігалося збільшення кількості волокнистих структур, переважно за рахунок колагенових волокон, а також зменшення інтенсивності васкуляризації у периваскулярному просторі. Виявлено незначне потовщення стінки артерій, спричинене набряком. Окремі ендотеліоцити залишалися набряклими, округлими, виявлялося їх пролабування у просвіт артерії. Цитоплазма визначалася світлою, ядра були нормохромними, лише в окремих випадках відмічалася гіперхромія. В просвіті окремих судин наявні групи злущених ендотеліоцитів та пристінкові агрегати еритроцитів.

Базальна мембрана була рівномірно гофрованою, без розривів. Значних змін у структурі еластичних волокон не спостерігалося, лише в окремих випадках мало місце їх розволокнення та фррагментація. Лейоміоцити середньої оболонки мали рівномірну товщину та помірну звивистість, спостерігалися окремі ділянки вакуолізації.

Адвентиція потовщена унаслідок розрихлення набряковою рідиною. У зазначеній групі дослідних тварин характерним було зменшення інтенсивності лімфоцитарної інфрільтрації медії, адвентиції та периваскулярних тканин порівняно з попередньою групою.

Крововиливів у периваскулярних ділянках та між м'язовими волокнами не виявлено. Навколо кровоносних судин наявний незначний набряк із розрихленням тканинних структур. Необхідно відмітити збільшення накопичення колагенових волокон порівняно з попередньою групою тварин поряд зі зменшенням кількості клітинних елементів (рис. 8).

Отже, у тварин групи пізнього реперфузійного періоду виявлено поступове повернення більшості досліджуваних морфологсрчних змін до рівня групи контролю.

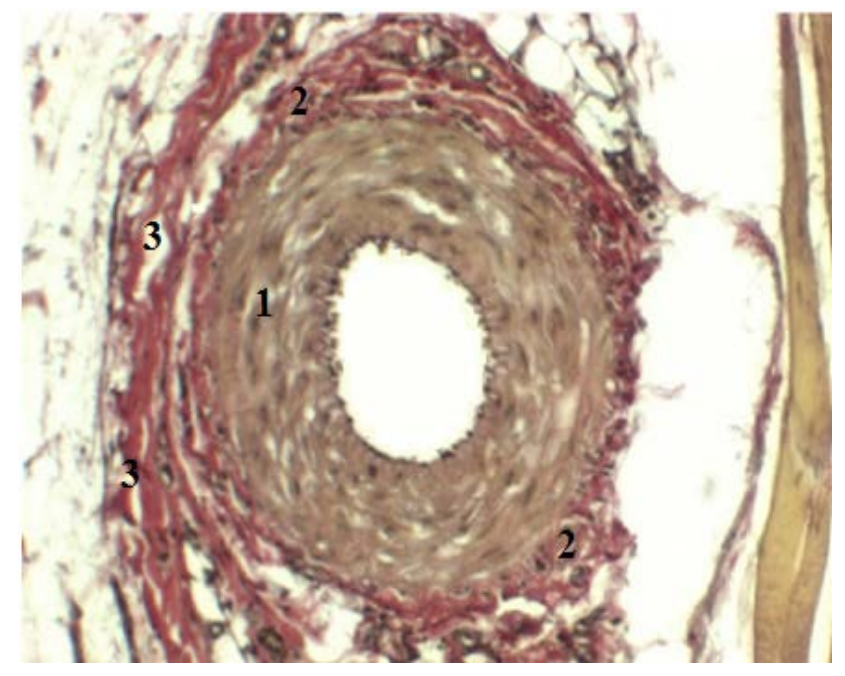

Рис. 7. Артерія гомілкової ділянки. Реперфузія через 7 діб. Забарвлення за ван Гізон. ×100.

Примітка. 1 - набрякла медія артерії; 2 - колагенові волокна в адвентиції артерії; 3 - колагенові волокна у периваскулярному просторі.

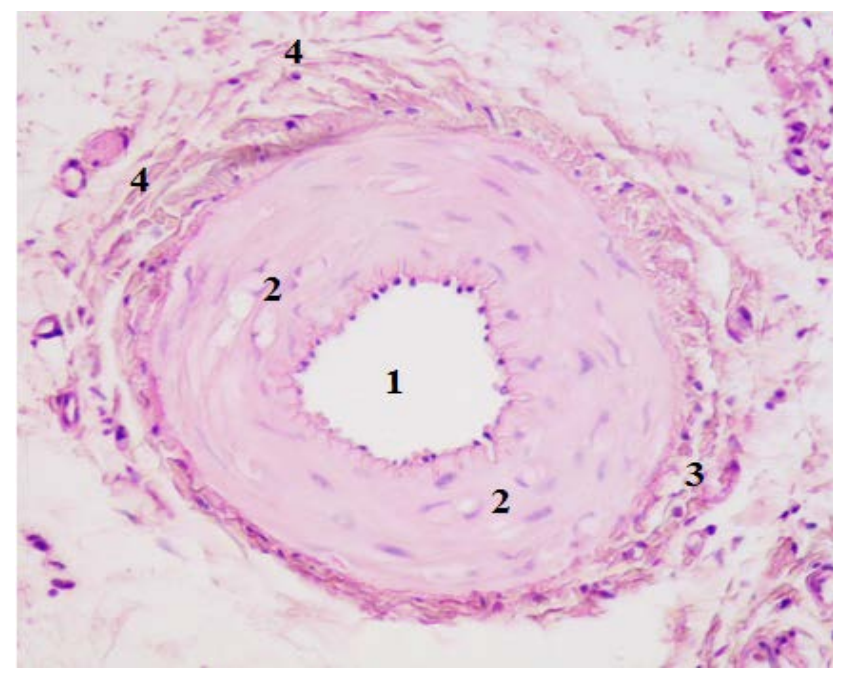

Рис. 8. Артерія гомілкової ділянки. Реперфузія через 14 діб. Забарвлення гематоксиліном та еозином. $\times 100$.

Примітка. 1 - просвіт артерії; 2 - ділянки вакуолізації у медії; 3 розрихлення периваскулярної тканини; 4 - накопичення волокнистих структур у периваскулярному просторі.

\section{висновки}

1. Морорологічними критеріями ремоделювання артерій стегнової, підколінної та гомілкової ділянок у ранньому реперорузійному періоді були гістологічні зміни усіх структурних елементів їхньої стінки, які проявлялися набряком і потовщенням усіх оболонок артерій, відшаруванням ендотеліоцитів, нерівномірною гофррованістю та розривами базальної мембрани, порушенням цілості еластичних волокон, вакуолізацією саркоплазми лейоміоцитів, лейкоцитарною інфрільтрацією м'язового шару та перивазального простору, а також периваскулярними діапедезними крововиливами

2. Дослідження структурних змін стінки артерій у щурів при гострій експериментальній ішемії за 
умов розвитку ішемічно-реперфузійних уражень у динаміці показало їхнє активне наростання до кінця раннього реперфузійного періоду, типізацію комплексу патоморорологічних проявів в усіх групах дослідження із найбільшим прогресуванням у групі дослідження з терміном реперфузії 1 доба.

3. Аналіз морфологічних змін стінки магістральних артерій у щурів при гострій експериментальній ішемії за умов розвитку пізнього періоду ішемічно-реперфузійного синдрому в динаміці показав ремоделювання судинного русла, яке ви-

\section{СПИСОК ЛІТЕРАТУРИ}

1. New tourniquet device concepts for battlefield hemorrhage control / J. F. Kragh, C. Murphy, M. A. Dubicket [et al.] // Army Med. Dept. J. - 2011. - P. 38-48.

2. Kumar K. Tourniquet application during anesthesia: "What we need to know?" / K. Kumar, C. Railton, Q. Tawfic // Journal of Anaesthesiology Clinical Pharmacology. - 2016. - Vol. 32, No. 4. - P. 424-430.

3. Use of a tourniquet in total knee arthroplasty: a systematic review and meta-analysis of randomized controlled trials / F. Jiang, H. Zhong, Y. Hong, G. Zhao // J. Orthop. Scien. - 2015. - Vol. 20, No 1. - P. 110-123.

\section{REFERENCES}

1. Kragh JF, Murphy C, Dubick MA, Baer DG, Johnson J, Blackbourne LH. New tourniquet device concepts for battlefield hemorrhage control. US Army Med Dept J. 2011;38-48.

2. Kumar K, Railton C, Tawfic Q. Tourniquet application during anesthesia: What we need to know? J Anaesthesiol Clin Pharmacol. 2016;32(4): 424-30. DOI: 10.4103/09709185.168174.

3. Jiang FZ, Zhong HM, Hong YC, Zhao GF. Use of a tourniquet in total knee arthroplasty: a systematic review and meta-analysis of randomized controlled trials J Orthop Sci. 2015;20(1): 110-23. DOI: 10.1007/s00776-014-0664-6. являлося у комплексі патоморфологічних змін усіх оболонок судинної стінки із зменшенням інтенсивності набряку та розвитком грануляційної тканини в адвентиції і периваскулярному просторі. При цьому суттєво зменшувалася також інтенсивність лімфоїдної інфрільтрації 3 відсутністю дрібних крововиливів та некротичних ділянок. Васкуляризація грануляційної тканини у периартеріальному просторі досягала максимуму в тварин через 7 діб реперфрузії і зменшувалась через 14 діб.

4. Геник С. М. Реперфрузійний синдром після реваскуляризації ішемії нижніх кінцівок / С. М. Геник, А. В. Симчич // Серце і судини. - 2016. - № 3. - С. 104-108.

5. Кутепов Д. Е. Патогенез синдрома ишемии-реперсузии / Д. Е. Кутепов, М. С. Жигалова, И. Н. Пасечник // Казанский медицинский журнал. - 2018. - № 99 (4). - С. 640-644.

6. Tennant $D$. The role of HIFs in ischemia-reperfusion injury / D. Tennant, N. J. Howell // Hypoxia. - 2014. Vol. 2. - P. 107-111.

7. Саркисов Д. С. Общая патология человека / Д. С. Саркисов, М. А. Пальцев, Н. К. Хитров. - М. : Медицина, 1997. - 608 с.

4. Henyk SM, Symchych AV. [Reperfusion syndrome after lower limb ischemia revascularization]. Sertse i Sudyny. 2016;3: 104-8. Ukrainian.

5. Kutepov DE, Zhigalova MS, Pasechnik IN. [Pathogenesis of ischemia-reperfusion syndrome]. Kazanskiy med zhurn. 2018;99(4): 640-4. DOI: 10.17816/KMJ2018-640. Russian.

6. Tennant D, Howell NJ. The role of HIFs in ischemiareperfusion injury. Hypoxia. 2014;2: 107-11. DOI: 10.2147/ HP.S49720.

7. Sarkisov DS, Palcev MA, Khitrov NK. General human pathology. [Общая патология человека] Moscow: Meditsina; 1997. Russian. 